\title{
ENHANCING UNDERSTANDING, FLOW AND SELF-EFFICACY IN LEARNERS WITH DEVELOPMENTAL AND ATTENTION DIFFICULTIES THROUGH ICT-BASED INTERVENTIONS
}

\author{
Hanne Voldborg Andersen [voldborg@learning.aau.dk], Elsebeth Korsgaard Sorensen \\ [elsebeth@learning.aau.dk], Aalborg University,Dept.of Learning and Philosophy, Krogstrade 3, 9220 \\ Aalborg Oest, Denmark [bttp:// wnw.en.aau.dk]
}

\begin{abstract}
The purpose of this paper is to investigate in which ways technologies may be used to increase inclusion and a feeling of flow and self-efficacy in learning processes when it comes to learners with developmental and attention deficits (focus learners) in a mainstream classroom. The paper is one piece of outcome of a wider study on ICT facilitated inclusion, and this current piece of research addresses the challenges of enhancing focus learners' comprehension when working with the curriculum. Several technologies have been tried out in a real school context and seven types of interventions are identified as valuable for focus learners' capability in learning processes. The paper discusses the findings and concludes that conscious use of technology-based interventions makes it possible to provide learning challenges balanced to the learners' individual skills. But a broader understanding and acceptance by all stakeholders of the specific challenges of this group of learners in mainstream educational systems seems needed to fulfil the potential.
\end{abstract}

\section{Abstract in Danish}

Formålet med denne artikel er at undersøge, hvorledes teknologier kan anvendes i det almene skolesystem som redskab for inklusion af elever med udviklings- og opmærksomhedsproblemer (fokuselever) og styrke elevernes oplevelse af flow og tiltro til egne evner (self-efficacy) i læreprocesser. Undersøgelsen er en del af et større studie om it-faciliteret inklusion, hvor denne artikel handler om udfordringer $\mathrm{i}$ forhold til at øge fokuselevernes forståelse for det faglige indhold. Adskillige teknologier har været afprøvet i en reel skolekontekst, og syv typer af interventioner er identificeret som værdifulde for fokuselevernes kapabilitet i læreprocesser. Artiklen diskuterer resultaterne og konkluderer, at bevidst brug af it-baserede interventioner gør det muligt at tilbyde læringsudfordringer tilpasset elevernes aktuelle faglige og kompetencemæssige niveau. Men det synes nødvendigt med en bredere forståelse og accept hos alle interessenter for denne gruppe elevers specifikke udfordringer $i$ det almene undervisningssystem, hvis dette potentiale skal realiseres.

Keywords: inclusion, ICT, special education, attention deficits, learning, differentiation

\section{Introduction}

Inclusion of learners with special educational needs (SEN) in mainstream schools appears an ambitious item in the educational-political agenda in Denmark, where bewilderment and frustration are common phenomena among teachers facing the challenge of teaching SEN learners (Baviskar, 2015). In general, teachers find themselves neither possessing the required specialized pedagogical knowledge and competencies to include youngsters with developmental and attention deficits (Danmarks Evalueringsinstitut, 2011) - nor the sufficient technological skills to utilise the affordances of digital learning resources for this group of learners (Andersen \& 
Sorensen, 2016a). Learners with Developmental and Attention Deficits (also named focus learners) form a broad and inhomogeneous group of children, who are challenged with respect to both life and learning. The term focus learners includes learners with Attention Deficit Hyperactivity Disorder (ADHD), Attention Deficit Disorder (ADD) or Autism Spectrum Disorder (ASD). To enable inclusion in terms of increasing presence, participation and achievements for focus learners, it is crucial that teachers have knowledge about these learners' specific challenges and competences: "In order truly to help someone else, I must understand more than he - but certainly first and foremost understand what he understands. If I do not do that, then my greater understanding does not help him at all" (Kierkegaard, 1859). Likewise, teachers must be able and willing to arrange learning environments, which take this knowledge into account: "If One Is Truly to Succeed in Leading a person to a Specific Place, One must First and Foremost Take Care to Find Him Where He Is and Begin There" (ibid.).

Children diagnosed with ASD often demonstrate restricted communication and social skills as well as a reduced repertoire of behaviours, interests or activities (Cihak et al., 2012). They might be unable to communicate their needs in an appropriate way or might engage in disruptive behaviours (ibid.), and their learning experiences will often be affected from echolalia, disorganisation, inattentiveness or stereotypic behaviours (Delano, 2007). Learners with ADD or ADHD are affected by the core symptoms of the diagnosis: attention difficulties and/or hyperactivity and impulsivity (Barkley, 2006). The problems include poor attention span, distractibility and difficulty staying on task, which impact their ability to manage time, to keep deadlines, to plan/organize schoolwork or to make friends. The symptoms are very sensitive to situation and context, the situated demands and the level of cognitive complexity in a task (ibid.). Low working memory often pose a barrier as it is necessary for controlling attention in complex cognitive processes such as learning, understanding and reasoning (de la Guía et al., 2015). Focus learners often lack self-regulation, which is why they master skills at a lower level than their peers. They often experience themselves unable to cope with demanding situations and feel incompetent about their performance. According to (Barkley, 2006) children with ADHD generally have low self-esteem and may easily be frustrated. That is why teachers must be aware to construct learning opportunities, which motivate these learners and encourage them to participate despite their problems.

\section{Theoretical Approach}

In Denmark focus learners with low self-esteem and lower skills are included in the mainstream education system without - or with limited - special educational support. They are taught in mainstream classes by mainstream teachers, who are searching for new ways to engage the focus learners and help them to enhance their feeling of flow (Csikszentmihalyi, 2014) and self-efficacy (Bandura, 1997) in task solving processes and their learning outcome. According to Flow Theory (Csikszentmihalyi, 2014), it is necessary to ensure an appropriate balance between a person's ability to do something and the challenge at hand to attain a feeling of satisfaction and inner motivation in a process. Flow can be experienced in situations, where a task is both challenging and shaped to the focus learner's skills, while an unbalance between challenge and ability triggers anxiety, worry, apathy or boredom as illustrated in Figure 1. 


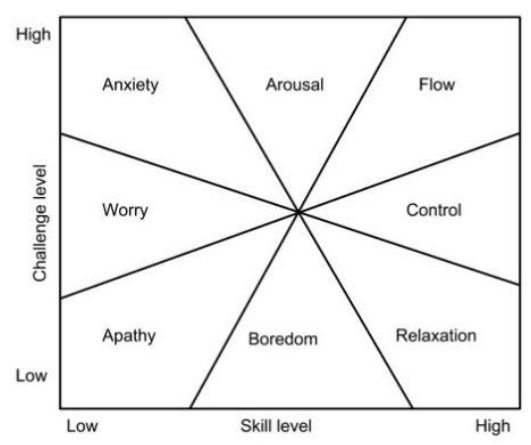

Figure 1. Flow illustrated as a harmonic balance between challenge and ability

Furthermore, a learner's belief in his or her ability to succeed in a situation or accomplish with a task (self-efficacy), also affects the learners' approach to tasks and challenges. Bandura's (1997) social cognitive theory describes how individual's actions and reactions are influenced by actions, which they have observed in others, and how persons with high self-efficacy are more likely to see challenging tasks as something to be mastered, rather than something to be avoided. In other words, if you are to change focus learners' behaviour, you must change their beliefs. Schaffer (2013) states with his research that flow only appears during the following conditions:

1. high perceived skills;

2. knowing what to do;

3. knowing how to do it;

4. knowing how well you are doing;

5. knowing where to go (if navigation is involved);

6. freedom from distractions and

7. high perceived challenges.

Technology today is a natural part of people's life and impact many aspects of education, training and development. Education is a human right, and disabled people should receive appropriate support. Assistive technologies (AT) are seen as solutions for providing this support and remove barriers in education (McKnight \& Davies, 2012). They are internationally recognised as "a particular valuable tool for people with disabilities... [in order to] ... improve their quality of life, reduce social inclusion and increase participation" (Waller \& Watkins, 2013). A large number of assistive learning technologies have been investigated (ibid.), but "there is perhaps a tendency for research to focus on the technology rather than its uses" (McKnight \& Davies, 2012). This counts for e.g. development of technological tools (Bul et al., 2015), comparing tools (Hill \& Flores, 2014) or evaluating the value of a function under specific circumstances (Kang et al., 2007). Furthermore, most literature on AT for the focus learners examines technologies used in therapy by psychologists (de la Guía et al., 2015) or by special educational teachers in special educational schools (Cihak et al., 2012). Therefore, the authors of this paper call for investigations of the use of AT in the mainstream classroom. This paper examines how ordinary teachers have used AT to help focus learners to a more constructive meeting with the learning content and, thus, experience a feeling of flow and self-efficacy in learning activities in mainstream classes. 


\section{Research Contexts and Design}

\section{Research Question}

This paper is an outcome from a wider research project, ididakt, running 2013-2016 (Sorensen, Andersen, \& Grum, 2013). The project has "tested digital learning resources and developed ICTbased pedagogies, where the possibilities for structuring working processes and stabilize focus in classroom activities are enhanced for children with developmental and attention deficits" (Ministeriet for Børn og Undervisning, 2012). The project has been focusing on "barriers and possibilities, when ICT-tool were used to create including learning environments for learners with developmental and attention deficits in mainstream classes in public schools" (ibid.).

The overall research questions were chosen in order to generate an understanding of both what, how and why:

- In which ways are focus learners challenged when participating and contributing academically and socially in the classroom? What are their specific needs?

- In which ways are teachers challenged when including focus learners in their classroom teaching? What are their specific needs?

- Which technologies could be implemented in the classroom activities, and in which ways would they be helpful to the focus learners? How would they fit into the learning environment?

- Which challenges occur, when implementing technologies in the classroom?

- Which support is needed, when implementing technologies in the classroom?

In order to answer these questions, the research design contains two concurrent research processes:

1. A Participatory Action Research Process - where schools and teachers are encouraged and prepared to use new pedagogical strategies and new technologies in the classroom activities and supported to develop their own practice while sharing their experiences with the researchers.

2. An Empirical Investigation Process - where data are collected, gathered, analysed and simultaneously used to both document the results of the study and inform the development processes at the participating schools.

A five-type-model of including ICT-based interventions is identified and described in earlier work from the ididakt project (Andersen \& Sorensen, 2015; Andersen \& Sorensen, 2017). This model is presented in Figure 2.

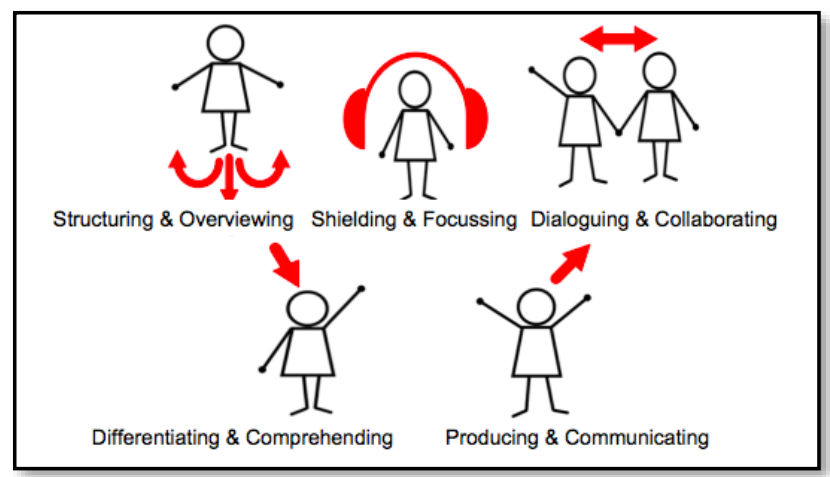

Figure 2. A five-type-typology for ICT-based interventions 
The intervention types are presented and discussed in separate research papers:

- Structuring \& Overviewing (Andersen \& Sorensen, 2016b; Sorensen \& Andersen, 2016a);

- Sbielding \& Focussing (Andersen, 2015);

- Producing \& Communicating (Sorensen \& Andersen, 2017) and

- Dialoguing \& Collaborating (Sorensen \& Andersen, 2016b).

This present paper frames the investigations of enhanced Differentiating \& Comprehending through ICT-based interventions in the classroom.

\section{Research Methodology}

Ididakt is an iterative and explorative research project, where data are collected in a real school context at public schools in Denmark. The study is mainly qualitative, but inspired by a mixed methods approach in the frame of Educational Design Research (EDR) (McKenney \& Reeves, 2012) with a hermeneutic-phenomenological interpretation of data. EDR is a "genre of research in which the iterative development of solutions to practical and complex educational problems also provides the context for empirical investigations, which yield theoretical understanding that can inform the work of others" (ibid.; p.7). EDR is not a fixed method. It is a genre, where multiple approaches can be combined considering the different initiating problems, research questions and contexts. EDR portrays a process, which can be described as a complex and multifaceted endeavour, defined by being theoretical oriented, interventionistic, collaborative, responsively grounded and iterative (ibid).

Mixing methods in EDR provides an opportunity to generate ecologically valid, relevant and robust knowledge, where methods, materials and settings for the study are closely related to real life situations (Brewer, 2000). The aim of an EDR study is to generate usable knowledge for researchers as well as practitioners. Since EDR is conducted in real life settings and data are developed in classrooms or other learning environments, the research design has to embrace a very complex system with many different participants, interactions and influencing factors. Multiple methods and methodological creativity seem crucial to capture the complexity. Different research questions and different research purposes also advocate for using a repertoire of different approaches.

As described above, there is no fixed receipt to follow, when conducting a mixed method study in the frame of EDR. But it is not the same as "anything goes" (Greene, 2007). Mixed methods research is defined as "research in which the investigator collects and analyses data, integrates the findings, and draw inferences using both qualitative and quantitative approaches in a single study or program of inquiry" (Teddlie \& Tashakkori, 2006; p.15). Greene (2007) challenges and extends this definition, as she seeks space for more than qualitative and quantitative traditions and calls for multiple different paradigms and methodological traditions. She perceives a strong link between intended purpose for mixing and the mixed methods design decisions. She states that methods are always implemented from within a particular assumptive framework, why selfconscious attention on this is needed. Such inquiry mixes theories, disciplines and methods, but try very carefully to handle all of them humbly respecting their different characteristics and underlying understandings of the social world and the knowledge we can have on this social world (ibid.).

\section{Research context}

The ididakt project is realized as a learning endeavour, where the authors/researchers have been professional dialog partners and facilitators in transformations processes at 11 schools, where 
they in collaboration with 46 teachers have examined the impacts of using ICT facilitated interventions in 26 classes. More than 500 learners from $1^{\text {st }}$ to $10^{\text {th }}$ grade (age 6-16 years) were included in the project - among them 56 focus learners with extensive developmental or attention deficit disorders. These 56 focus learners do not necessarily have a diagnose, but they are all described by their teachers as children who "breaks with age appropriate rules, norms and expectations to children in basic schools with a regular character over time" (Nordahl, Mausethagen, \& Kostøl, 2009; Dyssegaard, Larsen, \& Tiftikçi, 2013) and challenged in the field of ADHD, ADD or ASF in areas of:

- memory;

- attention;

- persistence;

- hyperactivity;

- impulsivity;

- behaviour;

- emotions;

- prosocial behaviour;

- having friends;

- understanding and conception;

- language and communication.

The 56 focus learners in the project are described with a test battery of both quantitative and qualitative tools, where the teachers have answered a number of questions according to the children's behaviour, well-being, academically outcome, working methods, social role etc. in the HOV-survey (Jensen de López, 2013), the SDQ - Strength and Difficulties Questionnaire (Obel et al., 2009), the ADHD-RS (Poulsen et al., 2009) and in a narrative template with descriptions on respectively a good and a bad day at school. The data from the screening has been used to:

1. Validate the relevance of the focus learners for the project;

2. Guide the teachers to choose pedagogical and technological interventions targeted the individual focus learners;

3. Indicate a progress by the focus learners during the intervention period (Andersen et al, 2016).

\section{Research Design}

In the Participatory Action Research (PAR) processes are the "researchers in close contact with 'practitioners' within a given field make analyses and experiments in the field and contributes with solutions to the social objectives being studied" (Brinkmann \& Tanggaard, 2015). "It is crucial for our data collection, that the unfolding research process goes hand in hand with the involved teachers' work and interventions into the field of study, so the process becomes a learning endeavour in terms of learning how to work with SEN learners and integrating ICT in the classroom." (Andersen \& Sorensen, 2015) The research design includes both perspectives: "Real change can come, when we focus not only on what and how things can be done, but when we also work on understand why" (McKenney \& Reeves, 2012; pp.1-2).

The researchers contribute with theoretical knowledge and understandings about inclusion, learning and technology. They participate as a professional dialogue partner in the transformation processes occurring at the schools (Jungk \& Müllert, 1989; Duus et al., 2012) and assist the teachers in their development of practice, while learning from their experiences (Sagor, 2000). 
The requirement to the researcher is to study the movements, but also initiate the actions, which generate learning in the field into a given objective (Duus et al., 2012; p.83).

The teachers are involved as co-researchers, where their active participation and actions are based on their own perceptions on problems in their local context, which might both enhance their understanding of the objectives, and generate ownership and empowerment (Freire, 1970). The tasks for researchers and teachers are listed in Table 1.

Table 1: Researchers' and Participants' roles and deliveries in Participatory Action Research (Duus et al., 2012)

\begin{tabular}{|c|c|c|c|}
\hline $\begin{array}{l}\text { Level of } \\
\text { effort }\end{array}$ & $\begin{array}{l}\text { The participant's task: } \\
\text { Develop practice }\end{array}$ & $\begin{array}{l}\text { Shared tasks: Collaborate, plan } \\
\text { and manage }\end{array}$ & $\begin{array}{l}\text { The researcher's tasks: } \\
\text { Running the business }\end{array}$ \\
\hline $\begin{array}{l}\text { Basis } \\
\text { level }\end{array}$ & $\begin{array}{l}\text { Deliver data } \\
\text { Co-produce new } \\
\text { knowledge } \\
\text { Test new knowledge } \\
\text { Transform knowledge } \\
\text { into practice }\end{array}$ & $\begin{array}{l}\text { Articulate problems and } \\
\text { objectives } \\
\text { Study learning processes } \\
\text { Work out contradictions and } \\
\text { conflicts } \\
\text { Support the process }\end{array}$ & $\begin{array}{l}\text { Collect data } \\
\text { Analyse data } \\
\text { Deliver new knowledge } \\
\text { Support transformation of } \\
\text { new knowledge }\end{array}$ \\
\hline $\begin{array}{l}\text { Meta } \\
\text { level }\end{array}$ & $\begin{array}{l}\text { Discuss appropriate ways } \\
\text { to initiate learning } \\
\text { processes }\end{array}$ & $\begin{array}{l}\text { Analyse the organisation as a } \\
\text { learning unit - create learning } \\
\text { strategies }\end{array}$ & $\begin{array}{l}\text { Give feedback on } \\
\text { participants learning } \\
\text { processes }\end{array}$ \\
\hline $\begin{array}{l}\text { End } \\
\text { level }\end{array}$ & $\begin{array}{l}\text { Develop and refine } \\
\text { practice }\end{array}$ & $\begin{array}{l}\text { Evaluate results, finish the } \\
\text { collaboration between } \\
\text { researcher and field }\end{array}$ & $\begin{array}{l}\text { Develop local and eventual } \\
\text { generalizable knowledge }\end{array}$ \\
\hline
\end{tabular}

The PAR process is scheduled to last two years and is running in two iterations with 5 schools in first iteration and 6 other schools in second iteration. The aim of this construction is to develop solutions in the first year in one context (Sandbox 1) and to test or refine them in another context the second year (Sandbox 2). The two iterations are generally identical, but with some minor differences, because the research design was slightly refined from Sandbox 1 to Sandbox 2.

\section{Data Collection Processes}

During each one-year iteration a rich empirical data set is collected consisting of teachers' statements at seminars/workshops/Skype meetings, in blog entries at a research blog, by researchers' observations of classroom activities or from ad hoc interviews or minor surveys as illustrated in Figure 3.

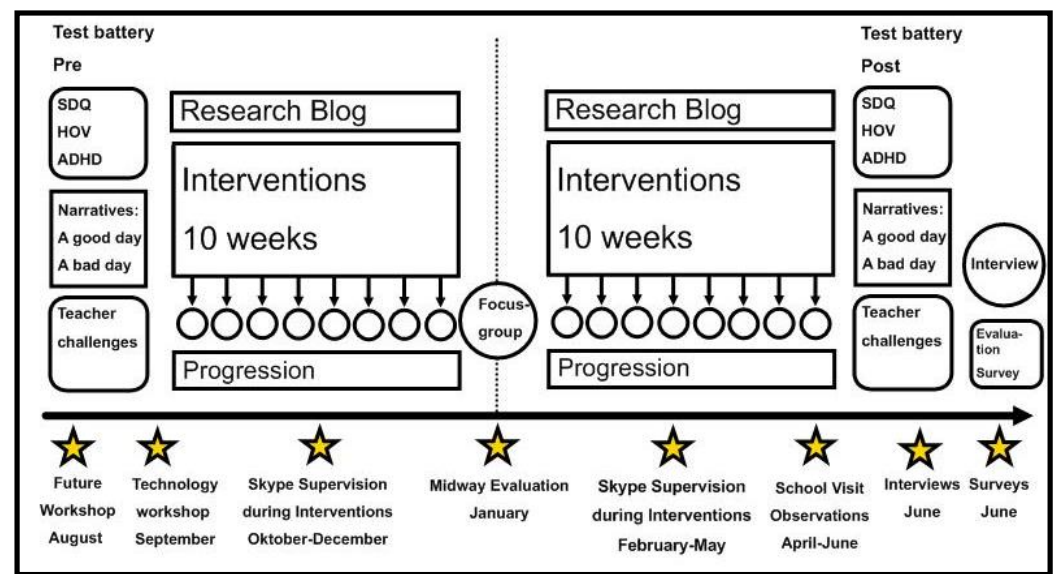

Figure 3. The research design for each iteration in Sandbox 1 and 2 (Andersen et al., 2016) 
Table 2: The data collection techniques and the generated data in the ididakt project

\begin{tabular}{|c|c|}
\hline Method & Aim \\
\hline Pre-post test battery & $\begin{array}{l}\text { Quantitative data on the focus learners' challenges in } \\
\text { classroom activities before and after use of ICT-based } \\
\text { interventions verify the focus learners' challenges and } \\
\text { describe their progress during the project. }\end{array}$ \\
\hline Pre-post test battery & $\begin{array}{l}\text { Qualitative data on the focus learners' challenges inform } \\
\text { the researchers and improve their recommendations and } \\
\text { support to the practitioners. }\end{array}$ \\
\hline Future workshop - teacher challenges & $\begin{array}{l}\text { Qualitative data generated, and to some extend quantified } \\
\text { and analysed, during the future workshops collaboratively } \\
\text { with the participants (by voting and arguing) by which } \\
\text { teachers' challenges are identified. }\end{array}$ \\
\hline $\begin{array}{l}\text { Evaluation survey - teachers } \\
\text { challenges }\end{array}$ & $\begin{array}{l}\text { Qualitative and quantitative data collected in a final survey } \\
\text { and combined with data from the Future workshop to } \\
\text { investigate teachers' progress during the project. }\end{array}$ \\
\hline Research blog & $\begin{array}{l}\text { Qualitative data collected in a shared research blog, where } \\
\text { teachers describe their experiments with ICT-based } \\
\text { interventions and the focus learners' reactions when using } \\
\text { technologies in the classroom activities. Researchers have } \\
\text { commented and facilitated the dialogue. }\end{array}$ \\
\hline Observations & $\begin{array}{l}\text { Qualitative data collected as field notes, photos and videos } \\
\text { from researchers' classroom observations of teachers' and } \\
\text { focus learners' advantages and challenges when using } \\
\text { technology in the classroom activities }\end{array}$ \\
\hline $\begin{array}{l}\text { Field notes and photos from seminars, } \\
\text { school visits, skype supervision etc. }\end{array}$ & $\begin{array}{l}\text { Qualitative data, which elaborate and clarify the } \\
\text { understandings from surveys or blog entries. The teachers } \\
\text { have opportunity to express whatever they feel and have } \\
\text { experienced in relation to the intervention processes. }\end{array}$ \\
\hline $\begin{array}{l}\text { Ad hoc unstructured and semi- } \\
\text { structured interviews, quick surveys or } \\
\text { written narratives to get a deeper } \\
\text { understanding of elements from } \\
\text { research blog or observations. }\end{array}$ & $\begin{array}{l}\text { Additional qualitative data collected to capture the } \\
\text { teachers' or learners' voices and gain a deeper } \\
\text { understanding on topics recognized in the other data sets } \\
\text { in proportion to e.g. the inclusion processes or their } \\
\text { experiences of the technology based interventions. }\end{array}$ \\
\hline
\end{tabular}

As illustrated in Table 2, both qualitative and quantitative data is collected both parallel and sequential but analysed and used separately in order to enlighten several perspectives by the overall research questions:

1. Map the challenges by the focus learners before and after the interventions.

2. Map the teachers' challenges in including classroom practices Knowing how to do it.

3. Map the used technology and the interventions in which technology was used Knowing where to go (if navigation is involved).

4. Map the learners' perspectives on inclusion and their use of technology.

5. Evaluate the value of the ICT-based interventions, when it comes to focus learners' presence, participation and contribution in the school.

6. Evaluate the interventions value for the teachers' practice.

7. Identify potentials and challenges when implementing and using technologies in the schools. 
8. Evaluate the value of the research/development program.

\section{Analysis and Findings \\ Data Analysis Processes}

The quantitative data from the Pre-Post test were analysed separately and independently by one of the co-researchers, who did not participate in the PAR. The results indicate if focus learners meet the inclusion requirements identified by teachers for this study (with attention and developmental difficulties). A descriptive statistic is presented as an average for the whole group before and after the ICT-interventions were introduced and as a percentage of focus learners with a score in respectively normal, borderline or high level. Statistically, comparisons of the groups score before and after the introduction of ICT-interventions were calculated using independent and repeated measures t-test with a significance level on $5 \%$ and by using the statistic SPSS program version 19 (Andersen et al., 2016).

The qualitative data were analysed from different perspectives, but in an overall phenomenological hermeneutic interpretation inspired by Ricoeur's hermeneutical function of distanciation, where the text becomes more "objective" and "have its own life", when it is being removed from the original authors intentions, meaning or significance (Ricoeur, 1973; Ricoeur \& Thompson, 2016; Dreyer \& Pedersen, 2010). The different qualitative data sets were converted into text and unified as a compiled 'story' of the case. After several readings new sub-stories were structured from different perspectives:

- The story of the technologies - which technologies were used, for what purpose and with which value?

- The story of each individual focus learner - which challenges, which technologies with which purpose and impact?

- The story of the teachers - which strategies and which challenges when implementing technologies

Inspired by Ricoeur, poetic narratives were used to derive a distance in the interpretation of qualitative data, qualify the interpretation by enabling a transformation from the authors intentions towards a deeper understanding of the referring objectives in the text. This analytic approach allows us to create narratives across data and the analytic process may be understood in four sequentially phases:

1. Converting speech into writing and naïve reading.

2. Rewrite the text to a structured work - as a new narrative.

3. During this work deduce a kind of being-in-the-world related to data.

4. Read, analyse and re-write the new structured work in a critical analysis and discussion to reach a higher level of understanding of the topic investigated.

During these iterations of analysis, patterns and explanations have emerged with both a deeper understanding of the focus learners' specific needs and the value of the ICT-based interventions and challenges for using technology in the school context. A preliminary analysis of data from Sandbox 1 compared initial findings from both qualitative and quantitative data, whereby a typology of five overall purposes for ICT-based interventions were identified and suggested (Andersen \& Sorensen, 2015; Andersen \& Sorensen, 2017). The typology was subsequent used as an analytical optic across all data sets from both Sandboxes, where findings were discussed in the light of our theoretical perspectives on inclusion, learning, psychology, technology and professional development. 


\section{Findings}

By categorising, analysing and interpreting data from a technology perspective, seven types of ICT-based interventions were identified as valuable enabling differentiation and enhancing comprehension in the learning activities:

1. the use of digital textbooks;

2. the use of digital course portals;

3. the use of video content;

4. the use of digital training resources;

5. the use of learning games;

6. the use of reading and writing technologies;

7. the use of digital summary or comprehension tools.

Several technologies were used in the 26 classes to facilitate differentiation and increase learners' comprehension in the seven types of interventions showed in Table 3.

Table 3: Technologies used in the seven intervention types and the prevalence of these

\begin{tabular}{|c|c|c|c|}
\hline Intervention type & Used technologies & In Classes & $\begin{array}{l}\text { Per cent of } \\
\text { Classes }\end{array}$ \\
\hline Digital Textbooks & Superbog.dk, Flexbøger.dk, E17.dk & 9 & $35 \%$ \\
\hline Digital Course Portals & Clioonline.dk, Gyldendal.dk, & 3 & $12 \%$ \\
\hline Video Content & $\begin{array}{l}\text { Youtube.com, Restudy.com, } \\
\text { Screencasts, }\end{array}$ & 21 & $81 \%$ \\
\hline Digital Training Resources & $\begin{array}{l}\text { Matematikfessor.dk, LytogStav.dk, } \\
\text { Quizlet.com }\end{array}$ & 15 & $58 \%$ \\
\hline Learning Games & $\begin{array}{l}\text { Runerod.dk, Villeby.dk, Kahoot.com, } \\
\text { QR-codes, }\end{array}$ & 9 & $35 \%$ \\
\hline $\begin{array}{l}\text { Reading/Writing } \\
\text { Technologies }\end{array}$ & $\begin{array}{l}\text { CDord, AppWriter, Ordbogen.com, } \\
\text { Google Translate }\end{array}$ & 22 & $85 \%$ \\
\hline $\begin{array}{l}\text { Individual or Shared } \\
\text { Summary/Comprehension } \\
\text { Tools }\end{array}$ & $\begin{array}{l}\text { Mindmap.com, Digital Portfolios, } \\
\text { Flipped Learning, Google Apps for } \\
\text { Education, Office365, Meebook, } \\
\text { ElevIntra, }\end{array}$ & 17 & $65 \%$ \\
\hline
\end{tabular}

The seven identified types of ICT-based interventions for differentiation and comprehension is presented and discussed in the rest of this section.

\section{Digital Textbooks}

Digital resources as Superbog.dk gives focus learners access to a collection of the same books as they can find at the school library. The digital books are nicely illustrated, and they can read them themselves or get reading help when necessary. When the book is finished, they can answer a few questions to check their understanding. The reading assistant tools are built in this learning resource which optimizes the functions. The focus learners are actively turning the pages over which help them to be attended in the reading processes. Resources as Flexbøger.dk offer learners a pdf-version of school books for several subjects while E17.dk have a large number of fiction and schoolbooks in both pdf-format or recorded audio books. With pdf-books learners have to use separately Reading Technologies, which functionality is very dependent on the quality of the pdf-files to be Optical Character Recognized (OCR-processed) and thereby readable. It is 
important, that the digital books provided offers the focus learners the same quality of reading experiences, same words and concepts and same intellectual level of language to stimulate their academically growth. Finally, digital books should offer more modalities - not less - to stimulate the readers' attention and with an expansion of expression strengthening their memory capacity.

In the ididakt classes, digital textbooks provided the focus learners with opportunities for using Reading Technologies (Text-to-speech) and listening to the written text if they are poor readers or if they are exhausted during the school day. Access to extensive libraries of digital textbooks enable focus learners to choose books of interest, which motivate their reading. They get an appropriate intellectual challenge AND necessary reading support, which facilitate a harmonic balance between challenge and ability (flow) and enable their independently reading (selfefficacy). In the books at Superbog.dk they are guided visually to know what to do, how to do and they are able to monitor their own progression in reading statistic and control questions. Digital text books as pdf-files in Flexbog.dk makes it as well easier to use digital writing support tools with an impact on both flow and self-efficacy:

"A couple of boys are now able to deliver a readable product, why they now get response as well" (Teacher G).

It is important, though, that these text files are accessible in and organized in a well-structured learning environment. Chaotic and confusing interfaces will rapidly steal the attention and disturb the reading processes. Accessibility from any platform in school or at home has been helpful for learners with poor memory or planning skills:

"Now books are not forgotten at home or disappeared in school. Reading support is at hand both in school and at home" (Teacher G).

Finally, have we observed, how focus learners use the digital text and audio books to calm down and take a break from impressions and expectations and 'recharge their batteries' during a school day.

\section{Digital Course Portals}

Publisher produces digital course portals as e.g. Clioonline.dk or Gyldendal.dk provide access to the full curriculum for a subject and contains texts, information, tasks, models etc. Focus learners might here find course content at different levels of complexity with digital reading support at hand, supplemented with materials in various modalities as e.g. pictures, videos, graphics, sound clips, links or interactive features. These multiple modalities offer the focus learners knowledge from different perspectives, and enable enhanced motivation for and comprehension of a topic in a harmonic balance between challenge and skills (flow). Focus learners have access to Digital Course Portals in both schools and at home. If the Portals are well structured and well designed with a simple visual navigation design, the focus learners will easily know what to do and how to use the resources:

"The focus learners get started really focused. They are looking for information for answering an assignment. They read and make a quiz about what is learned. They choose between easy or difficult texts. They follow different media links and watch different kind of movies" (4 $4^{\text {th }}$ grade).

Focus learners monitor their own progression at the site: 


\author{
"The reading $\log$ has been helpful to $N$ (boy, $10^{\text {th }}$ grade) to keep track of his answers - it \\ offers him an overview and simplify his options" (Teacher K).
}

When all materials are compiled in the same digital environment, it seems to provide focus learners with an overview of a subject content, which they themselves are hardly able to foster. They do not have to search for e.g. lyrics, background knowledge and analytic tools in different resources, because they are all at hand at the course portal. Teachers have observed, how focus learners easily work both individually and collaborate with peers with more surplus, when the learning content are unified in one place.

\title{
Video Content
}

Video has been used to support differentiation and comprehension at the schools, but differently with learners as either consumers or producers of videos. Teachers have provided learners with videos from either Youtube.com or Restudy.com or made their own videos as e.g. screencasts to the learners. Youtube.com offers both teachers and learners a huge number of video content that can be used as content in or as supplementing explanations to classroom activities. But the resource is also able to provide the learners a smooth road to entertainment and interruption of the learning processes. It seems important to give the focus learners a specific link to a specific video for a specific task. They are too often disappeared in searching activities when they have to find videos themselves.

Restudy.com provide video content for all subjects and academic topics related to higher secondary school and high school activities. The videos are made by teachers and directly related to a specific part of the curriculum. The resource was very useful to our oldest focus learners, who have used the videos to be prepared before the lessons (flipped learning), instead of reading during the lessons or as a source for repetition to get ready for the final tests. Finally, teachers have produced their own video content using technologies as Screen o-matic.com, Screencastify.com or their mobile phone video camera. They have expressed that it takes time for them to find the right videos at Youtube.com and they often prefer another explanation in the videos than provided. But some of the teachers are reluctant and insecure when it comes to produce their own videos. They want to create a perfect product, and that is as well a very time consuming activity. They might be willing to accept an easier cut-to-go product - or take out a subscription to video resources as Restudy.com, where both teachers and learners can rapidly find videos for a specific theme or topic.

In one class ( $2^{\text {nd }}$ grade) the teachers were experimenting on simple videotaping the classroom instructions with an iPad during the lessons and sharing these videos on the fly with the learners in an online file archive. They find this method valued, given that learners during the lessons are using the videos to remember and repeat the instructions. It seems to be of more value for the peers than the focus learners, but the teachers experienced then more time to help the focus learners in another way in the classroom activities, when the peers where more self-supporting by the videos.

When videos are provided as a part of the academic dissemination to all learners, a more equal access to information are given:

\section{"All learners must benefit from them. The instructions must be brief and clear" (Teacher B).}

For younger focus learners it seems to be important, that the videos are short and only deliver one perspective at a time. It is harder for them to navigate in a long video and remember steps and explanations. The teachers recommend a number of short videos for the youngest focus 
learners instead. When classes are watching video at the classroom board, many focus learners take a break and drop out of activities. Videos seem to be more useful for individuals or peers, when the focus learners can interact with or dialog about the content.

Some focus learners do not at first benefit from videos:

"The impact is higher for learners with academically surplus energy. It is challenging, that the learners not are able to ask questions. I must still give them oral explanations and they can afterward use the videos to remember, what to do. That makes in return many learners selfsufficient" (Teacher F).

But videos offer many focus learners a fine balance between challenge and skills:

"M (boy, $10^{\text {th }}$ grade) can be concentrated very long time by them. He understands the Pythagoras after watching explanations and gives right answers afterwards." (Teacher K).

Learners have easier access to knowledge, they can replay if needed and receive information in their own speed. Focus learners interact autonomously with the content and express self-efficacy:

"I am learning better with the computer because there are more options. I can e.g. watch video - and look at both video and text. It is easy for me to make notes because I can pause the video. It is much easier to use a video than to ask my teacher all the time" (girl, $8^{\text {th }}$ grade).

Differentiation and comprehension is not only supported when focus learners are consumers of videos, but also when they act as producers. In the ididakt project, videos have also been used to sustain and visualise, what is learned - as an externalised memory or an alternative to classroom presentations. Such videos help focus learners to remember and guide them, when shifting from one activity to another, and illustrate their progression as well:

"I would continue with this method, because my focus learner (boy, 6 $6^{\text {th }}$ grade) had so much drive when creating the video. Normally he would not take part in such activities" (Teacher $B)$.

During the project video presentations are made by vulnerable learners as a scaffold or an alternative to classroom presentation, where the learners production of the video has prompted a feeling of confidence about their skills (self-efficacy):

"Presentation via video for B (boy, $4^{\text {th }}$ grade). It was a good idea. He really liked that option. But when he saw his peers present, he wanted to do the same. So he did not use his video... He has so much non-attendance and it is very difficult for him to get into flow. Video presentation is a good idea as a backup. It would be fine, if everybody had this opportunity, and just chose in the moment, if they would like to present via video or in real life. Then it would be less stigmatising” (Teacher F).

\section{Digital Training Resources}

The schools have access to different kinds of digital training resources as e.g. Matematikfessor.dk, LytogStav.dk, Quizlet.com or apps for more operant conditioning learning activities like e.g. PopMath, 120 ord or Cut\& Slice. Such activities have traditionally often been used in for Special Educational Needs learners. Many of our focus learners also find those activities attractive and seem to calm down and take a break from impressions and expectations, similar to the way they act with digital books described above. 
Digital Training Resources provide learners rehearsing specific skills and possibilities for choosing challenges that fit their capability. The program scaffolds them to know what to do, how to do and how well they are doing. They work in their own speed with a minimum of distractions and often feel both flow and self-efficacy, when they find the programs interesting. Many focus learners express, that they like these predictable resources, and teachers observe learners more focused and active in learning activities, where task solving is guided and response or help is available:

"M (boy, 10 th grade) uses matematikfessor.dk. He follows explanations using good, closed, beadphones and is able to stay at the tasks even with some noise around him. Normally, be would do notbing” (Teacher K).

It is important, though, to be aware if the learners are rehearsing any valuable skills and how they could be used in other contexts, as they do not want to be passivated in trivial and unemployable activities.

\section{Learning Games}

Different kinds of game based learning activities have been tried out during the project using resources as e.g.

Runerod.dk, Villeby.dk, Kahoot.com or QR-codes. At Villeby.dk has the youngest focus learners $\left(1^{\text {st }}-4^{\text {th }}\right.$ grade $)$ experienced a virtual world with game based activities for Math, Danish, English, Nature \& Science, Artwork, Religion etc. The children were engaged in the tasks, but the teachers have noticed how important it was for the focus learners to show what they have achieved and work against a goal. When the resource was used as a random activity for the focus learners they were less attended and did less care if the task were appropriately solved. Meaning is important. When it comes to learning games, some focus learners got a new role in the classroom:

\section{"We used a learning game. $N$ (boy, $\sigma^{\text {th }}$ grade) was really in play here and able to belp his peers" (Teacher B).}

The learner states that he likes learning games because of the up-tempo and activities:

"It is not boring and slow".

Some of the classes in $4^{\text {th }}-6^{\text {th }}$ grade have tested a Math learning game at Runerod.dk. It is an online game similar to World-of-Warcraft, where they visit a fantasy world and need to solve different kinds of math quest to finish the game. There were quite a lot of reading in the game, but the environment and the task were engaging, which powered some of the focus learners to read more than they usually did. The learning game did - like the Digital Training Resources scaffold the learners and tell them what to do, how to do it and monitor how well they were doing. They can work in their own speed with minimal distractions and obtain a feeling of flow. Several schools have tested this game and the teachers' judgement is clear. Focus learners were more motivated and engaged when playing learning games if the tasks in the game were appropriate to their skills:

"A (boy, $4^{\text {th }}$ grade) was very focused at the game. He wanted to continue at home, which is totally new for him. He should also continue in the school, but unfortunately it is finished in few hours. It should have been more extensive - they are finishing the game to fast" (Teacher C). 
Some teachers designed game based learning activities by themselves to enhance focus learners' motivation, e.g. a Run \& Spell game with QR codes to provide restless focus learners with more mobility in the lessons:

\section{"I find these games really funny" (girl, $4^{\text {th }}$ grade).}

In the $6^{\text {th }}-10^{\text {th }}$ grade teachers have used online game based resources like Kahoot.com, Quizlet.com or quizzes related to superbog.dk (Digital books), Restudy.dk (Video content), or Course Portals to test and monitor how well the learners were doing. Both teachers and learners find quizzes and games motivating because of the competition between learners and the immediate feedback. We have observed very engaged learners when these games have been used as a variation in the teaching sessions, but we have also experienced how some of the focus learners expressed, that they feel stress, anxious and worry, when they participated in time limited activities with tasks beyond their actual skills.

\section{Assistive Reading and Writing Technologies}

Due to their deficits challenges many of the focus learners are behind when it comes to academically skills as reading and writing. Other with a low arousal, persistence or attention were just as much distracted and on 'overtime work', and therefore only achieved very little. Most of them were developmentally years behind their peers and could need a helping hand by using assistive reading and writing technologies as e.g. CDord, AppWriter, Ordbogen.com, Google Translate, Siri etc.

Assistive reading technologies read text aloud for learners while writing technologies offers learners word suggestions, help them spelling or write what they are saying. Assistive Reading and Writing Technologies helps focus learners to feel flow and self-efficacy:

"We have used it for some years now. Earlier, I found it very difficult to write a text. I made a lot of failures and all sounded wrong. Now it is easier. When I got it, I wrote a whole story, and it was almost right. Then I was happy and joyful and thought it was funny to write" (girl, $4^{\text {th }}$ grade).

Almost every focus learner in the project mention Assistive Reading and Writing Technologies as valuable tools they would recommend to other learners. Slow readers or learners with reading difficulties appreciate to "hear the reading while being attentive at the text" ( $6^{\text {th }}$ and $7^{\text {th }}$ grade). Reading and writing technologies helps them to work more independently (self-efficacy):

"Then I do not need help from the teacher all the time" (boy, $6^{\text {th }}$ grade).

\section{Individual and Shared Summary/Comprehension Tools}

The classes in ididakt have used several and very different digital resources as e.g. Mindmap.com, Google Apps for Education, Office365, Meebook or ElevIntra with the aim of providing learners an individual or shared space for summarising what is learned or how concepts and topics could be understood. The learners use these technologies to create e.g.

- a Word-of-Wisdom-blog in math with their own explanations on calculation rules or equation solving processes;

- a Concept-mind-map in Danish, where they build their own glossary and explain concepts with words and photos or 
- an Expectation-Diary, where they are dialoguing with their teachers and meta reflect on their own learning progression and achievements.

Such interventions give learners a place for reflection, reification and evaluation of what they have done and learned. It seems valuable for focus learners to compile their experiences of successes and development, as they often experience their school work very fragmented and need help to establish an overview. They will often meet with a feeling of lacking skills, why an evident reification of their progression might impact their self-esteem and self-confidence. To build these summaries activate their thinking, their reflection and allow them to articulate their understanding in preferred modalities. They can return to them for repetition and memory support.

Likewise, many of the schools start during the project to use a shared digital production/working platform at either Google Apps for Education or Office365 to gather all learning material for the classes. It was a learning process to design and use these new Virtual Learning Environments (VLEs), but after a period of experiments, adaptions and modification they offered the focus learners a great help in their learning processes:

\begin{abstract}
"Google Websites is a good resource in Danish Language, where all topics from all years are compiled. All learners can see, what the peers have made. They learn to find help from other learners and be respectful for that. We have e.g. structured a novel reading course with on page for introduction to the novel, another with tasks before reading, a third while reading and a fourth after reading. Tasks are compiled and different modalities are used for information, instruction, analysis models etc. The learners return to and compile with earlier work. It works well for all learners that content and contributions in a subject are structured and gathered. They can add text, pictures or videos to support their individually comprehension" (Teacher B).
\end{abstract}

For focus learners with lacking ability for overviewing and navigating it is important to be aware of the fact that these challenges occur both in the real and the virtual world. It is important that focus learners are offered a helping hand with organizing their digital learning environment if the potential of the technologies should be fulfilled. Unstructured and poor organized digital learning tasks and environments often lead to cognitive overload resulting in loss of control and a feeling of frustration, anger or apathy.

\title{
Discussion and Perspectives
}

Even though we during this paper have enlightened how valuable digital resources can be, our research has also uncovered some negative implications. In order to keep a high arousal, a feeling of control and flow it is important that focus learners meet both high-perceived challenges and skills. But many of our focus learners are - due to their deficits - years behind their peers developmentally, socially and academically. In mainstream classrooms, they often meet the same tasks as their peers, and even though they might get a helping hand or an assisting tool, they still will be evaluated against the same curriculum. This impacts their experience of self-efficacy or being good enough.

Teachers are frustrated, when they cannot appreciate and acknowledge focus learners' progression with marks in relation to their actual growth.

"I tell bim he is doing well, but tomorrow he will have his marks, and then I know his courage will fail and he will stop trusting me." (Teacher J).

We cannot expect learners to grow in the same speed. 
The same problem is noticed in relation to assistive reading and writing technologies: When teachers encourage learners to use text-to-speech or speech-to-text-tools other teachers, parents or peers express, it is a kind of "cheating". It seems important to clarify the purpose of reading and writing activities for all stakeholders: "To be able to read or write" or "To learn as much as possible and express knowledge and thoughts"? An inclusive school should generate a Universal Design for Learning approach - not only when developing, buying or providing assistive tools but also when it comes to pedagogy and policies.

We have experienced how pedagogical deliberate introductions to and use of Virtual Learning Environments, digital resources and assistive tools impact focus learners' self-efficacy in terms of knowing what and how to do things:

"We have many academically weak children in our classes and observe how CDord (reading/writing technology) makes them much more autonomic. It is difficult to find good reading materials to weak readers, but now they can unassisted read and be more at the same level as their peers" (Teacher J).

Unfortunately, we have seen, that many teachers do not know how to use these technologies, which is why they cannot support focus learners and leave them on their own.

The value of technology-based interventions and assistive tools depends on the individual focus learner's deficits and challenges. When it comes to e.g. learners who are years behind their peers with small vocabulary, poor comprehension or weak memory, they might need alternative pedagogical initiatives and approaches than the mainstream teaching practice offers:

"He (boy, $6^{\text {th }}$ grade) has been at a special education school for three years. He cannot just jump into the curriculum here. He can read using technology, but he might not understand the words. We must help bim step by step" (Teacher $G$ ).

It seems difficult for teachers to help learners with weak working or short time memory:

"M (girl, $4^{\text {th }}$ grade) finds math videos of relevance for what we are doing in the lessons. $V$ ideos for the lower classes are short and simple. Then she is concentrated. When they are getting longer with more operations involved - it is difficult for her to remain on task." (Teacher D).

We will suggest further research in rehearsing memory capability, which seems crucial for a major part of our focus learners learning outcome.

Gathering all learning materials into online portals improve focus learners access to learning experiences (e.g. enable differentiation, several modalities or repetition). Navigation in the VLE seems problematic for some focus learners why teachers must be aware of designing a simple and clear path to materials and keep away unnecessary distractions. Teachers must see themselves as role models for learners and provide focus learners simple learning pathways and structures to scaffold them in both the digital and real-world classroom. Schools must have a critical view on Human Computer Interaction at learning resources: How easy and intuitive is the navigation when the learner is 6,10 or 14 years old? It is a child friendly learning environment or a measure friendly technology?

Tests, quizzes, games, training resources etc. have been used in many of the investigated classes with both positive and negative impact for focus learners. With no differentiation and evaluation against the same goals, with time-limitations and competition it seems as a stressful adventure for 
our focus learners. It might be fairer to them, if learning groups were designed after stage rather than age. And it might be of greater value, if schools were more focused on facilitation of reification, meta-reflections and formative evaluation instead of narrow-minded focus on measuring, data documentation and summative quantitative reports of learning outcome.

Teachers have during the project described, how they often feel guilty, because they know full well the focus learners' specific needs without being able to offer them what is needed. Half of the teachers do not feel competent pedagogically or technologically to design technology-based interventions for the target group and state that they neither have sufficient time for designing individual material, explanations and structures for a focus learner's full day at school. Many examples of successful interaction of technology and pedagogic have been found. But they are used in flash - from time to time - and not a consistent practise in the focus learners' time at school.

\section{Conclusion}

This paper has investigated the potential of technology-based interventions for differentiating learning experiences and increasing comprehension by learners with attention and developmental deficits (focus learners). We have observed how use of seven types of technology-based interventions:

1. digital textbooks;

2. digital course portals;

3. video content;

4. digital training resources;

5. learning games;

6. reading and writing technologies and

7. Individual or shared summary tools.

In many ways have supported the focus learners in their learning activities and helped them to experience more flow and self-efficacy in their school work.

Digital books give focus learners access to both fiction and non-fiction at a higher intellectual level than they might be able to read on their own. Assistive reading and writing software help them to work faster and perform at a higher level. Digital course portals and digital summary tools offer them an overview on the curriculum and easy 24/7/365 access to material in many modalities. Video content, learning games and digital training resources has in this project proved to be motivating and engaging for the focus learners and offered them new ways to work with the curriculum.

For teachers with both pedagogical and technological insight it seems to be possible to exploit this favourable potential in their classroom teaching and increase a feeling of flow and selfefficacy in learning processes among this group of vulnerable focus learners. Flow might appear when the technologies makes it easier for the focus learners to join, overview, understand, participate and contribute to the learning activities, while self-efficacy emerge when the technologies helps them to work more independently and autonomous.

All together has this suite of technology-based interventions proven to offer the focus learners learning tasks in respect to their specific challenges and skills. When used consciously and systematic, both teachers and learners has succeeded in taking advantage of the power of technologies to help learners overview what to do, how to do, where to go and how well they are 
doing. Our research has unveiled how technologies can help minimizing distractions and provide an overview for unattended learners. However, it may also lead to cognitive overload when without structuring and navigating support. Teachers' classroom management is necessary in both real world and virtual environment settings.

If technology should be utilised to its full including potential, it is necessary for schools not only to buy and provide technologies, but also use it in a Universal Design for Learning (UDL) approach that gives all individuals equal opportunities to learn, allow them to meet learning challenges balanced to their actual skills and to grow in their own speed. The seven types of technology-based interventions for differentiating learning experiences and increasing comprehension suggested in this article, could help teachers to foster such an including learning environment, where learners are to be meet as whom they are and become access to appropriate pedagogical and technological support.

Even though this investigation has exhibited many examples where technology and pedagogy interact successfully and increase focus learners' ability to be more self-driven and more actively participating in an including learning community, good examples only still appear in flashes and yet not as a consistent practise in the focus learners' time at school. Organisational limitations and inconveniences in the school system seems in many cases to interfere with and even destroy the inclusion vision and intensions. We might be able to include all learners in the mainstream school system, but we cannot expect them to grow in the same speed. If they were joining classes after stage rather than age it might be easier for the teachers to provide them learning activities at their actually developmentally and academically level and sincerely appreciate and acknowledge their progression with marks in relation to their actual growth. Teachers need both sufficient digital and special educational competencies if they should be able to design technology-based interventions for the target group, and need as well more time for designing individual materials, explanations and structures for a focus learner's full day at school.

Finally, it might be of great value if schools had a more critical view on Human Computer Interaction in the digital learning resources bought and provided to focus learners: Is it a child friendly and appealing learning environment? And what do we want to achieve when using these technologies? To evolve an including school system, it seems necessary to foster a much broader and deeper understanding and acceptance by all stakeholders around this group of focus learners with respect to their specific challenges in the mainstream educational system.

\section{References}

1. Andersen, H. V. (2015). Supporting Inclusion of Learners with AttentionDeficit/Hyperactivity Disorder in Sound-Field-Amplification-Systems. Proceedings of the $1^{\text {st }}$ D4Learning International Conference Innovations in Digital Learning for Inclusion, 1-8. Aalborg: Aalborg University Press.

2. Andersen, H. V., \& Sorensen, E. K. (2015). Technology as a Vehicle for Inclusion of Learners with Attention Deificits in Mainstream Schools. Proceedings of the European Distance and E-Learning Network 2015 Annual Conference Barcelona, 9-12 June, 2015, 720-730. Barcelona: EDEN.

3. Andersen, H. V., \& Sorensen, E. K. (2016a). Empowering Teachers and their Practices of Inclusion through Digital Dialogic Negotiation of Meaning in Learning Communities of Practice. Paper presented at the The EdMedia World Conference on Educational Media and Technology, 27th to 30th June 2016, Vancouver, British Columbia, Canada. 
4. Andersen, H. V., \& Sorensen, E. K. (2016b). Powerlessness or Omnipotence - the Impact of Structuring Technologies in Learning Processes for Children with Attention and Developmental Deficits. Paper presented at the $1^{\text {st }}$ EAI International Conference on Design, Learning \& Innovation, Esbjerg.

5. Andersen, H. V., \& Sorensen, E. K. (2017). Technology as a Vehicle for Inclusion of Learners with Attention Deficits in Mainstream Schools. In U. Bernath \& A. Szucs (Eds.), Best of Eden 2015 (1-13). Retrieved from http://www.eurodl.org/materials/special/2016/Barcelona_114_Andersen_Sorensen.pdf

6. Andersen, H. V., Sorensen, E. K., Jensen de Lopéz, K., \& Jensen, R. H. S. (2016). It-baseret inklusion af elever med udviklings- og opmarksomhedsforstyrrelser i folkeskolen (Forskningsrapport). Aalborg: Aalborg Universitet.

7. Bandura, A. (1997). Self-efficacy: the exercise of control. New York: W.H. Freeman.

8. Barkley, R. A. (2006). Attention-Deficit Hyperactivity. A Handbook for Diagnosis and Treatment (3 ${ }^{\text {rd }}$ ed.). New York: Guilford Press.

9. Baviskar, S. (2015). Dokumentationsprojektet: Kommunernes omstilling til oget inklusion pr. marts 2015. Institut for Uddannelse og Pædagogik (DPU), Aarhus Universitet: SFI - Det Nationale Forskningscenter for Velfærd.

10. Brewer, M. (2000). Research design and issues of validity. In H. T. Reis \& C. M. Judd (Eds.), Handbook of research methods in social and personality psychology (pp. 3-16). Cambridge, UK: Cambridge University Press.

11. Brinkmann, S., \& Tanggaard, L. (2015). Kvalitative metoder: en grundbog. Kbh.: Hans Reitzel.

12. Bul, K. C. M., Franken, I. H. A., van der Oord, S., Kato, P. M., Danckaerts, M., Vreeke, L. J., Willems, A., van Oers, H. J. J., van den Heuvel, R., van Slagmaat, R., \& Maras, A. (2015). Development and User Satisfaction of "Plan-It Commander", a Serious Game for Children with ADHD. Games for Health Journal, 4(6), 502-512. https:// doi.org/10.1089/g4h.2015.0021

13. Cihak, D. F., Kildare, L. K., Smith, C. C., McMahon, D. D., \& Quinn-Brown, L. (2012). Using Video Social Stories to Increase Task Engagement for Middle School Students With Autism Spectrum Disorders. Behavior Modification, 36(3), 399-425. https://doi.org/10.1177/0145445512442683

14. Csikszentmihalyi, M. (2014). Applications of Flow in Human Development and Education: The Collected Works of Mihaly Csikszentmibalyi. New York: Springer.

15. Danmarks Evalueringsinstitut. (2011). Indsatser for inklusion i folkeskolen. Kbh.: Danmarks Evalueringsinstitut.

16. Delano, M. E. (2007). Video modeling interventions for individuals with autism. Remedial and Special Eduation, 28, 33-42.

17. Dreyer, P. S., \& Pedersen, B. D. (2010). Distansering i Ricoeurs fortolkningsteori: fortællinger i et studie af det levede liv med kronisk sygdom og hjemmerespirator. Tidsskrift for Sygeplejeforskning.

18. Duus, G., Husted, M., Kildedal, K., \& Laursen, E. (2012). Aktionsforskning: en grundbog. (D. Tofteng, Ed.). Frederiksberg: Samfundslitteratur.

19. Dyssegaard, C. B., Larsen, M. S., \& Tiftikçi, N. (2013). Effekt og padagogisk indsats ved inklusion af born med sarlige behov i grundskolen: systematisk review. Dansk Clearinghouse for Uddannelsesforskning. 
20. Greene, J. C. (2007). Mixed methods in social inquiry (1 ${ }^{\text {st }}$ ed.). San Francisco, CA: Jossey-Bass.

21. de la Guía, E., Lozano, M. D., \& Penichet, V. M. R. (2015). Educational games based on distributed and tangible user interfaces to stimulate cognitive abilities in children with ADHD. British Journal of Educational Technology, 46(3), 664-678. https://doi.org/10.1111/bjet.12165

22. Hill, D. A., \& Flores, M. M. (2014). Comparing the Picture Exchange Communication System and the $\mathrm{iPad}^{\mathrm{TM}}$ for Communication of Students with Autism Spectrum Disorder and Developmental Delay. TechTrends, 58(3), 45-53. https://doi.org/10.1007/s11528-014-0751-8

23. Jensen de López, K. (2013). Hukommelse, Organisering og Vedholdenhed skemaet: HOV-skemaet et kort sporgeskema til vurdering af eksekutive funktioner hos born. Center for Developmental and Applied Psychological Science.

24. Jungk, R., \& Müllert, N. R. (1989). Håndbog i fremtidsvarksteder. Kbh.: Politisk revy.

25. Kang, H. W., Zentall, S. S., \& Burton, T. L. (2007). Use of images in instructional technology for children with attentional difficulties. Proceedings of the $6^{\text {th }}$ international conference on Interaction design and children - IDC '07, 12). New York, New York, USA: ACM Press. https://doi.org/10.1145/1297277.1297303

26. Kierkegaard, S. (1859). Synspunktet for min Forfattervirksombed. En ligefrem Meddelelse, Rapport til Historien. C. A. Reitzels Forlag.

27. McKenney, S. E., \& Reeves, T. C. (2012). Conducting educational design research. New York: Routledge.

28. McKnight, L., \& Davies, C. (2012). Current Perspectives on Assistive Learning technologies. University of Oxford: The Kellogg College Center for Research into Assistive Learning Technologies. Retrieved from http://www.kellogg.ox.ac.uk/wpcontent/uploads/2015/03/Current-Perspectives-on-Assistive-Learning-Technologies.pdf

29. Ministeriet for Børn og Undervisning (2012). Udmontning af pulje til It-baserede laringsformer/padagogik og redskaber rettet mod fagligt svage elever og elever med sarlige behov.

30. Nordahl, T., Mausethagen, S., \& Kostøl, A. (2009). Skoler med liten og stor forekomst av atferdsproblemer. En kvantitativ og kvalitativ analyse av forskjeller og likheter mellom skolene. (No. 3) (p. 119). Høgskoln i Hedmark.

31. Obel, C., Dalsgaard, C., Stax, H., \& Bilenberg, N. (2009). Spørgeskema om barnets styrker og vanskeligheder (SDQ-Dan) - et nyt instrument til screening for psykopatologi i alderen 4-16 å. Videnskab, Ugeskerift for Lager, 165(18), 462-465.

32. Poulsen, L., Jørgensen, S. L., Dalsgaard, S., \& Bilenberg, N. (2009). Dansk standardisering af attention deficit/hyperactivity disorder-ratingskalaen. Videnskab, Ugeskrift for Lager, 171(18), $1500-1504$.

33. Ricoeur, P. (1973). The hermeneytic function of distanciation. Philosophy Today, 17, 88-96.

34. Ricœur, P., \& Thompson, J. B. (2016). Hermeneutics and the human sciences: essays on language, action, and interpretation. New York: Cambridge University Press.

35. Sagor, R. (2000). Guiding school improvement with action research. Alexandria, VA: Association for Supervision and Curriculum Development.

36. Schaffer, O. (2013). Crafting Fun User Experiences: A Method to Facilitate Flow. Retrieved from https://www.researchgate.net/publication/272181532_Crafting_Fun_User_Experiences_A_ Method_to_Facilitate_Flow 
37. Sorensen, E. K., \& Andersen, H. V. (2016a). Amplifying the process of inclusion through a genuine marriage between pedagogy and technology. Paper presented at the Eden Annual Conference 2016, Budapest.

38. Sorensen, E. K., \& Andersen, H. V. (2016b). Learning Together Apart - the Impact on Participation when Using Dialogic Educational Technologies for Kids with Attention and Developmental Deficits. Paper presented at the $1^{\text {st }}$ EAI International Conference on Design, Learning \& Innovation, Esbjerg.

39. Sorensen, E. K., \& Andersen, H. V. (2017). Strengthening inclusion of learners with attention difficulties through interventions with digital technology in processes of production. European Journal of Open, Distance and E-Learning (EURODL), 20(1), 45-60. Retrieved from http://www.eurodl.org/materials/contrib/2017/Sorensen_Andersen.pdf

40. Sorensen, E. K., Andersen, H. V., \& Grum, H. (2013). Intercultural Dialogic eLearning: A Tool for Fostering Shared Understanding and Sustainable Competence Development in Practices of Inclusion. Proceedings of World Conference on Educational Multimedia, Hypermedia and Telecommunications 2013, 389-397. Victoria, Vancouver Island: AACE.

41. Teddlie, C., \& Tashakkori, A. (2006). A general typology of research designs featuring mixed methods. Research in the Schools, 13(1), 12-28.

42. Waller, T., \& Watkins, A. (2013). Information and Communication Technology for Inclusion. Research Literature Review. Brussels: European Agency for Development in Special Needs Education. Retrieved from https://www.european-agency.org/sites/default/files/ict4i-researchliterature-review_ICT4I-Research-Literature-Review.pdf 